\title{
NUOMONĖS LYDERIŲ KOMUNIKACIJOS POVEIKIS VARTOTOJŲ PIRKIMO ELGSENAI ELEKTRONINÉSE VAISTINĖSE
}

\author{
Birutė Pockevičiūtė, Regina Motienė \\ Kauno kolegijos Medicinos fakulteto Farmakotechnikos katedra
}

Raktažodžiai: vartotojai, pirkimo elgsena, nuomonès lyderiai, elektroninès vaistinès.

\begin{abstract}
Santrauka
Sparti interneto technologijų ir Web 2.0 saityno plètra paskatino farmacijos įmones orientuotis ị komunikaciją elektroninèse vaistinėse, pasitelkiant nuomonès lyderius. Mokslinių tyrimų rezultatai atskleidé, kad nuomonès lyderių patyrimu grindžiama komunikacija elektroninèse vaistinèse daro teigiamą poveiki vartotojų suvokimui, todèl šị poveikị svarbu ịvertinti. Tam tikslui reikalingi išsamesni tyrimai, nes aktualu teoriškai pagrịsti ir empiriškai patikrinti nuomonès lyderių komunikacijos poveikị vartotojų suvokiamai utilitarinei, hedonistinei vertei ir pirkimo elgsenai. Tyrimo objektas - nuomonès lyderių komunikacijos elektroninèse vaistinėse, vartotojų suvokiamos utilitarinès ir hedonistinès vertès bei pirkimo elgsenos sąsajos. Tyrimo tikslas - nustatyti nuomonès lyderių komunikacijos elektroninėse vaistinèse poveikị vartotojų suvokiamai utilitarinei, hedonistinei vertei bei pirkimo elgsenai. Tyrimo metodai. Mokslinès literatūros palyginamoji analizè ir sisteminimas. Empirinis kiekybinis tyrimas - anoniminè anketinè apklausa. Empirinio tyrimo rezultatu apdorojimui ir analizei naudota statistinè programa SPSS Statistic 23.0, taikant aprašomosios statistikos bei koreliacinès ir tiesinès regresijos analizès metodus. Tyrimo rezultatai. Nustatytas statistiškai reikšmingas teigiamas, stiprus ryšys tarp nuomonès lyderių komunikuojamos elektroninèse vaistinèse vaizdingos, informatyvios, įsimintinos, įdomios žinutès ir vartotojų suvokiamos utilitarinès ir hedonistinès vertès savybių. Nuomonès lyderių komunikacinė žinutė vartotojams teikia laimès ir malonumo jausmą, ji suvokiama kaip originali ir kelianti susižavejjimą. Išvados. Didžiausią poveikị vartotojų suvokiamai utilitarinei vertei daro nuomonès lyderių asmeninès savybès (kompetentingumas, objektyvumas, patikimumas ir fizinis patrauklumas).
\end{abstract}

Ivadas

Vartotojų patirtis ir jų poreikių patenkinimas daro stiprų poveikị pirkimo elgsenai elektroninèse vaistinėse $[1,6-8,14]$. Mokslininkai teigia, kad nuomonès lyderių komunikacija elektroninèse vaistinèse grindžiama socialiniu pažinimu, tarpasmeniniais ryšiais ir patyrimu. Nuomonès lyderių komunikacija elektroninèse vaistinėse vartotojams gali sukelti teigiamas, neigiamas arba neutralias emocijas ir formuoti naują požiūrị i prekes ar paslaugas, taikant ịgytą patirtí, tačiau tai įmanoma tik veiksmingai ir tikslingai išreiškiant komunikacijos turinị komunikacinèje žinuteje $[3,5,7,15]$.

Vartotojų pirkimo elgseną elektroninèse vaistinèse lemia nuomonès lyderių patirties dalijimosi ir vartotojų patyrimų sąveika $[4,13]$. Vartotojų suvokta utilitarinè (prekès ar paslaugos funkcija, kokybè, kaina, nauda ir kt.) ir hedonistinè (malonumas, nuoširdumas, laimè ir kt.) verte tarpusavyje koreliuoja ir daro poveiki pirkimo elgsenai $[2,11,12]$ (1 pav.).

Nuomonès lyderių perteikiama hedonistinès ir utilitarinès vertès tarpusavio sąveika gali daryti poveikị vartotojų pasitenkinimui bei pirkimo elgsenai elektroninèse vaistinèse. Esant šių verčių sąveikai, galima paveikti vartotojų suvokimą apie prekių ar paslaugų naudą [12].

Nuomonès lyderių komunikacijos elektroninèse vaistinèse metu po patyrimo suvoktos vertès didinimo procesai aprèpia prieraišumą prie prekių ar paslaugų (skatinama hedonistinè vertė) ir teikia funkcinę informaciją (skatinama utilitarinè vertè). Moksliniai tyrimai įrodè, kad šių verčių sąveika gali ne tik gerinti vartotojų patirties formavimą, bet ir neigiamai ji paveikti, jei bus pasirinkta netinkama komunikacija elektroninèse vaistinėse, tikslinè rinka, komunikacinès žinutès siuntėjas ar netinkamas informacijos turinys $[2,10,11]$.

Svarbu įvertinti nuomonès lyderių poveikị ne tik vartotojų suvokiamai utilitarinei ir hedonistinei vertei, bet ir pirkimo elgsenai elektroninèse vaistinèse, atsižvelgiant i nuomonès lyderių komunikacinès žinutès charakteristikas ir jos teikejo asmenines savybes $[2,9]$. Anot Cheung, Thadani ir kt. (2010), atlikta daug ịvairių nuomonès lyderių komunikacijos socialiniuose tinkluose poveikio mokslinių tyrimų, 
tačiau išpopuliarejjus elektroninėms vaistinėms, tyrimų šiame komunikacijos kanale vis dar trūksta [7].

Nuomonès lyderių komunikacijos efektyvumas elektroninèse vaistinėse priklauso nuo asmeninių, tarpasmeninių, socialinių ir komunikacinès žinutès charakteristikos veiksnių. Remiantis moksliniais šaltiniais, nustatyti nuomonès lyderių komunikacijos elektroninėse vaistinėse antecedentai: komunikacinès žinutès argumentavimo kokybè ir šaltinio patikimumas. Šie antecedentai lemia informacijos prièmimą. Komunikacinès žinutės argumentavimo kokybė priskiriama žinutès charakteristikos veiksniams, o žinutès siuntėjo patikimumas - asmeniniams komunikacijos elektroninèse vaistinèse efektyvumo veiksniams [14].

Šiuo metu ypač svarbu formuoti vartotojų požiūrị ir kurti naujas patirtis, naudojant įvairias komunikacines priemones elektroninèse vaistinėse. Vartotojų suvoktos vertès, papildytos patyrimu, tarpusavyje koreliuodamos, kuria naują požiūri ir formuoja pirkimo elgseną [15].

Tyrimo tikslas - nustatyti nuomonès lyderių komunikacijos elektroninèse vaistinèse poveikị vartotojų suvokiamai utilitarinei, hedonistinei vertei bei pirkimo elgsenai.

\section{Tyrimo metodai}

Atliktas teorinis ir empirinis nuomonès lyderių komunikacijos socialiniuose tinkuose poveikio vartotojų suvokiamai utilitarinei, hedonistinei vertei ir pirkimo elgsenai elektroninèse vaistinèse tyrimas. Teorinèms studijoms taikyti mokslinès literatūros palyginamosios analizès ir sisteminimo metodai. Atliekant empirini tyrimą, taikytas kiekybinis metodas - anoniminé anketiné apklausa. Gauti empirinio tyrimo rezultatai apdoroti ir analizuoti naudojant statistinę programą

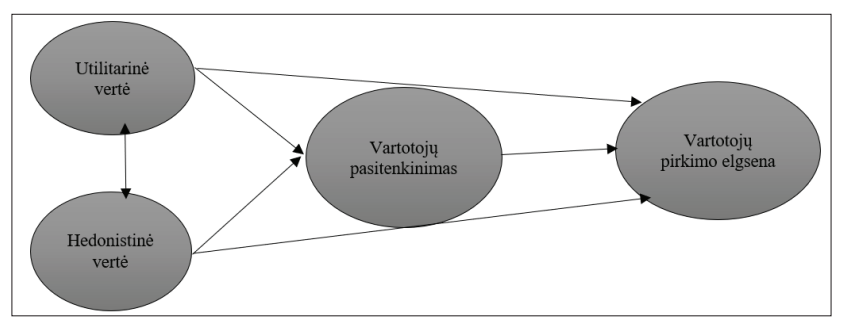

1 pav. Vartotojų suvokiamos utilitarinès ir hedonistinès vertès poveikis pirkimo elgsenai elektroninèse vaistinèse.

1 lentelė. Koreliacija tarp nuomonès lyderių asmeninių savybių, žinutės charakteristikos ir vartotojų suvokiamos utilitarinès vertès.

\begin{tabular}{|l|l|c|}
\hline \multicolumn{3}{|c|}{ Vartotojų (N=325) suvokiama utilitarinė vertė } \\
\hline $\begin{array}{l}\text { Nuomonės lyderių komuni- } \\
\text { kacinė žinutė }\end{array}$ & Spearman Correlation & $0,845^{* *}$ \\
\hline $\begin{array}{l}\text { Nuomonės lyderių asmeni- } \\
\text { nės savybės }\end{array}$ & Spearman Correlation & 0,932 \\
\hline
\end{tabular}

SPSS Statistic 23.0, taikant aprašomosios statistikos bei koreliacinès analizès metodus.

Kolmogorovo Smirnovo $Z$ testo rezultatai parodè, jog teiginiai nèra pasiskirstę pagal normalujị skirstinį $(p=0,000)$, todèl skaičiuojant koreliaciją tarp kintamujų naudotas Spirmeno (Spearman) koreliacijos koeficientas. Spearman koeficientas matuoja ranginius ryšius tarp skalès ar ranginių kintamujų ir jis yra tinkamas, nepriklausomai nuo to, koks pasiskirstymas tarp kintamujų [16].

Prieš pradedant nuomonès lyderių komunikacijos elektroninėse vaistinėse poveikio vartotojų suvokiamos utilitarinès, hedonistinès vertès ir pirkimo elgsenos tyrimo rezultatu analizę, nustatyti tyrime dalyvavę respondentai, priklausantys tiriamajai visumai.

Tyrime dalyvavo 474 respondentai, iš kurių 149 nepastebi nuomonès lyderių komunikacijos vaistinių tinklų elektroninèse vaistinėse, o 325 ją pastebi. Tyrime dalyvavo 361 moteris ir 113 vyrų. Respondentai buvo įvairaus amžiaus, tačiau daugiau kaip pusè $(52,45$ proc.) - nuo 18 iki 25 metų.

Daugiau nei pusė $(53,74$ proc.) respondentų turi aukštajj išsilavinimą. Kiti - vidurinị (27,1 proc.), aukštesnijji (8,2 proc.), pagrindini ( 2,78 proc.) ir profesini ( 2,35 proc.).

\section{Rezultatai ir jų aptarimas}

Atlikta gautujų duomenų koreliacijos analizè tarp nuomonès lyderių komunikacinès žinutės elektroninėse vaistinèse charakteristikų, nuomonès lyderių asmeninių savybių, vartotojų suvokiamos utilitarinès, hedonistinès vertès ir pirkimo elgsenos. Šių kintamujų vertinimo rezultatai: jei p reikšme mažesnė už pasirinktajį reikšmingumo lygmenį $\alpha-0,05$, koreliacinis ryšys laikomas statistiškai reikšmingu.

Analizès metu pastebèti itin stiprūs koreliaciniai ryšiai tarp nuomonès lyderių komunikacinės žinutės charakteristikų (vaizdingumo, informatyvumo, ịdomumo), nuomonès

2 lentelè. Koreliacija tarp nuomonès lyderių asmeninių savybių, žinutès charakteristikos ir vartotojų suvokiamos hedonistinès vertès.

\begin{tabular}{|l|l|c|}
\hline \multicolumn{2}{|c|}{ Vartotojų (N=325) suvokiama hedonistinė verte் } \\
\hline $\begin{array}{l}\text { Vartotojų suvokiama utilita- } \\
\text { rinė verte் }\end{array}$ & Spearman Correlation & $0,803^{* *}$ \\
\hline $\begin{array}{l}\text { Vartotojų suvokiama hedonis- } \\
\text { tinè verte }\end{array}$ & Spearman Correlation & 0,832 \\
\hline
\end{tabular}

3 lentelė. Koreliacija tarp vartotojų suvokiamos utilitarinès, hedonistinès vertès ir pirkimo elgsenos.

\begin{tabular}{|l|l|c|}
\hline \multicolumn{3}{|c|}{ Vartotojų (N=325) pirkimo elgsena } \\
\hline $\begin{array}{l}\text { Vartotojų suvokiama utilita- } \\
\text { rinė vertė }\end{array}$ & Spearman Correlation & $0,883^{* *}$ \\
\hline $\begin{array}{l}\text { Vartotojų suvokiama hedonis- } \\
\text { tinė vertė }\end{array}$ & Spearman Correlation & 0,832 \\
\hline
\end{tabular}


lyderių asmeninių savybių (kompetentingumo, patikimumo, objektyvumo, fizinio patrauklumo) ir vartotojų suvokiamos utilitarinès vertès (prekès ar paslaugos funkcijos). Koreliacijos koeficiento reikšmès pateikiamos 1 lentelejje.

Remiantis gautais rezultatais galima teigti, kad nuomonès lyderiai, kurie komunikuoja elektroninèse vaistinèse siųsdami ịdomią, informatyvią, vaizdingą komunikacinę žinutę ir joje perteikia asmenines savybes, daro stiprų poveiki vartotojų suvokiamai prekès ar paslaugos funkcinei vertei. Atlikta ryšių tarp nuomonès lyderių komunikacijos elektroninėse vaistinėse asmeninių savybių ir vartotojų suvokiamos utilitarinès vertès analizė atskleidè statistiškai reikšmingą teigiamą, labai stiprų ryšį tarp kintamujų $(\mathrm{p}<0,05)$.

Atlikta duomenų koreliacinè analizè tarp nuomonès lyderių elektroninèse vaistinėse komunikuojamos žinutès, asmeninių savybių ir vartotojų suvokiamos hedonistinès vertės. Rezultatai pateikiami 2 lentelèje.

Analizès rezultatai parodè statistiškai reikšmingą teigiamą ryši tarp kintamujų $(\mathrm{p}<0,05)$. Remiantis gautais rezultatais, ryšys tarp nuomonès lyderių elektroninèse vaistinėse komunikuojamos žinutės bei asmeninių savybių ir vartotojų suvokiamos hedonistinès vertès gali būti laikomas stipriu. Galima daryti išvadą, kad tarp nuomonès lyderių elektroninèse vaistinèse komunikuojamos žinutès charakteristikų ir vartotojų suvokiamos hedonistinès vertės yra statistiškai reikšmingas teigiamas stiprus ryšys. Tai reiškia, kad nuomonès lyderių komunikuojama veiksminga žinutė elektroninèse vaistinèse daro stiprų poveikị vartotojų suvokiamai hedonistinei vertei. Be to, galima teigti, kad nuomonès lyderių komunikaciné žinutè vartotojams teikia laimę, malonumą, yra originali, kelia susižavèjimą.

Koreliaciné analizė tarp vartotojų suvokiamos utilitarinès, hedonistinès vertès bei pirkimo elgsenos atskleidè, kad tarp kintamujų yra statistiškai reikšmingas teigiamas ryšys $(p<0,05)$. Koreliacijos rezultatai pateikiami 3 lentelejje.

Ryšys tarp vartotojų suvokiamos utilitarinès vertès ir pirkimo elgsenos gali būti laikomas stipriu. Tai reiškia, kad nuomonès lyderių komunikacinès žinutės informacija, esant patyrimui ir vartotojų suvoktai utilitarinei vertei, daro stiprų poveikị pirkimo elgsenai. Galima daryti išvadą, kad yra statistiškai reikšmingas teigiamas stiprus ryšys tarp vartotojų suvokiamos utilitarinès vertės ir pirkimo elgsenos.

3 lentelëje pateikti duomenys rodo, kad ryšys tarp vartotojų suvokiamos hedonistinès vertès ir pirkimo elgsenos taip pat gali būti laikomas stipriu, tačiau šiek tiek silpnesniu, nei tarp utilitarinès vertės ir pirkimo elgsenos. Tai reiškia, kad nuomonès lyderių praktiniu patyrimu grịsta komunikacinès žinutės informacija ir vartotojų suvokta hedonistinè vertè daro stiprią įtaką pirkimo elgsenai. Remiantis gautais duomenimis, galima daryti išvadą, kad nustatytas statistiškai reikšmingas teigiamas stiprus ryšys. Tai reiškia, kad nuomonès lyderių veiksminga komunikacine žinute perduota patirtimi grịsta informacija ir vartotojų suvokta utilitarinè, hedonistinè verte daro stipru poveikị pirkimo elgsenai.

Remiantis koreliacijos analizès rezultatais, galima teigti, jog yra statistiškai reikšmingas teigiamas stiprus ryšys tarp nuomonès lyderiu komunikuojamos elektroninėse vaistinėse vaizdingos, informatyvios, ịsimintinos bei įdomios žinutès ir vartotojų suvokiamos utilitarinès ir hedonistinès vertès savybių. Nuomonès lyderių išreiškiamas kompetentingumas, objektyvumas, patikimumas ir fizinis patrauklumas turi dar stipresnị poveikị vartotojų suvokiamai utilitarinei, o šiek tiek mažesnị, tačiau taip pat stiprų poveikị hedonistinei vertei. Galima teigti, kad nuomonès lyderių komunikacinè žinutè vartotojams teikia laimès ir malonumo jausmą, suvokiama kaip originali ir kelianti susižavejjimą. Daroma išvada, kad yra statistiškai reikšmingas teigiamas stiprus ryšys tarp vartotojų suvokiamos utilitarinès, hedonistinès vertès ir pirkimo elgsenos.

\section{Išvados}

1. Atlikus mokslinių tyrimų analizę, nustatyta, jog komunikacija elektroninèse vaistinèse neatsiejama nuo vartotojų suvokiamos utilitarinès, hedonistinès vertés ir pirkimo elgsenos. Pastebèta, kad nepakanka mokslinio tyrimo studijų, nagrinėjančių nuomonès lyderių poveikị vartotojų suvokiamai utilitarinei, hedonistinei vertei ir pirkimo elgsenai.

2. Identifikuotos vartotojų suvokiamos hedonistinès vertės savybės: malonumas, laimès jausmas, susižavèjimas ir originalumas. Atskleistos vartotojų suvokiamos utilitarinès vertės savybės: paslaugos ar prekès nauda, prekès kaina, kokybė ir funkcionalumas. Mokslinès literatūros analizès eigoje nustatyti vartotojų pirkimo elgsenos motyvai: prekès įsigijimas, naudojimas, patirties dalijimasis po pirkimo, pakartotinis pirkimas. Mokslinès literatūros analizès metu identifikuotos nuomonès lyderių asmeninès savybės, komunikacinès žinutès charakteristikos.

3. Koreliacijos analizès rezultatai parodè statistiškai reikšmingą teigiamą stiprų ryšị tarp nuomonès lyderių elektroninèse vaistinėse komunikuojamos vaizdingos, informatyvios, įsimintinos, įdomios žinutès ir vartotojų suvokiamos utilitarinès, hedonistinès vertẻs savybių. Nuomonès lyderių komunikacinè žinutė vartotojams teikia laimès ir malonumo jausmą, ji suvokiama kaip originali ir kelianti susižavejjimą. Atlikus duomenų koreliacinę analizę, pastebètas labai stiprus nuomonès lyderių asmeninių savybių (kompetentingumas, objektyvumas, patikimumas ir fizinis patrauklumas) poveikis vartotojų suvokiamai utilitarinei vertei, o hedonistinei - šiek tiek mažesnis. Nustatytas statistiškai reikšmingas tei- 
giamas stiprus ryšys tarp vartotojų suvokiamos utilitarinės, hedonistinès vertès ir pirkimo elgsenos.

\section{Literatūra}

1. Aydinli A, Bertini M, Lambrecht A. Price promotion for emotional impact. Journal of Marketing 2014;78(4):80-96. https://doi.org/10.1509/jm.12.0338

2. Bhargave R, Chakravarti A, Guha A. Two stage decisions increase preference for hedonic options. Organizational Behavior and Human Decision Processes 2015;1(30):123-135. https://doi.org/10.1016/j.obhdp.2015.06.003

3. Brown J, Broderick AJ, Leeword N. Word of mouth communication within online communities: conceptualizing the online social network. Journal of Interactive Marketing 2007;21(3):120 .

https://doi.org/10.1002/dir.20082

4. Lin HC. How political candidates' use of Facebook relates to the election outcomes. International Journal of Market Research 2017;59(1):77-96.

https://doi.org/10.2501/IJMR-2017-004

5. Lin, HC, Swarna H, Bruning PF. Taking a global view on brand post popularity: Six social media brand post practices for global markets. Business Horizons 2017;60(5):621-633.

https://doi.org/10.1016/j.bushor.2017.05.006

6. Chen Sh, Glass DH, McCartney M. Characteristics of successful opinion leaders in a bounded confidence model. Physica A 2016;4(49):426-436.

https://doi.org/10.1016/j.physa.2015.12.107

7. Cheung M, Luo C, Sia C, Chen H. Credibility of electronic word of mouth: informational and normative determinants of online consumer recommendations. International Journal of Electronic Commerce 2009; 13(4):1-9.

https://doi.org/10.2753/JEC1086-4415130402

8. Sudha M, Sheena K. Impact of influencers in consumer decision process: the fashion industry. SCMS Journal of Indian Management 2017;2(4):154-162.

9. Sweeney CJ, Mazzarol T, Soutar NG. Factors influencing word of mouth effectiveness: receiver perspectives. European Journal of Marketing 2018; 3(4):344-364.

https://doi.org/10.1108/03090560810852977

10. Risselada H, Verhoef PC, Bijmolt THA. Indicators of opinion leadership in customer networks: self-reports and degree centrality. Mark Lett 2016;2(7):449-460. https://doi.org/10.1007/s11002-015-9369-7

11. Roggeveen AL, Grewal D, Townsend C, Krishnan R. The impact of dynamic presentation format on consumer preferences for hedonic products and services. Journal of Marketing 2015;79(6):34-49.

https://doi.org/10.1509/jm.13.0521

12. Eisingerich AB, Chun H, Liu Y, Jia H, Bell SJ. Why recommend a brand face-to-face but not on Facebook? How word-of-mouth on online social sites differs from traditional word-of-mouth. Journal of Consumer Psychology 2015;25(1):120-128.

https://doi.org/10.1016/j.jcps.2014.05.004

13. Sudha M, Sheena K. Impact of influencers in consumer decision process: the fashion industry. SCMS Journal of Indian Management 2017;31(6): 21-34.

14. Wang Y, Yu Ch. Social interaction-based consumer decision making model in socialcommerce: the role of word of mouth and observational learning. International Journal of Information Management 2015:37(3),179-189.

https://doi.org/10.1016/j.ijinfomgt.2015.11.005

15. Zhao Y, Zhang L, Tang M, Kou G. Bounded confidence opinion dynamics with opinion leaders and environmental noises. Computers \& Operations Research 2016:74,205-213.

https://doi.org/10.1016/j.cor.2015.07.022

16. Piligrimienė Ž. Marketingo tyrimų duomenų analizè SPSS programa, 2016.

\section{IMPACT OF OPINION LEADERS 'COMMUNICA- TIONS ON ELECTRONIC MEDICINES ON CONSUM- ER PURCHASE BEHAVIOR \\ B. Pockevičiūtė, R. Motienė}

Keywords: consumers, buying behavior, opinion leaders, epharmacies.

Summary

In an ever-changing and dynamic world, the rapid development of Internet technologies and Web 2.0 web sites has prompted pharmaceutical companies to focus on communication in e-pharmacies with opinion leaders. Research findings have shown that opinion leaders 'experience-based communication in e-pharmacies has a positive impact on consumers' perceived utilitarian and hedonistic value. However, it is important to assess not only the impact of opinion leaders on consumer-perceived utilitarian and hedonistic value, but also the impact on consumer buying behavior in epharmacies. Given the need for further research into the impact of opinion leaders' communication on e-pharmacies on consumers' perceived utilitarian, hedonistic, and purchasing behavior, it is expedient to theoretically substantiate and empirically examine the effects of opinion leaders' communications on consumer perceived utilitarian, hedonistic, and purchasing behavior.

The object of the study is the relationship between opinion leaders' communications in electronic pharmacies, consumer-perceived utilitarian and hedonistic values, and purchasing behavior.

The aim is to determine the effect of opinion leaders' communication in e-pharmacies on consumer-perceived utilitarian, hedonistic value, and purchasing behavior.

Objectives of the research: a) to substantiate the significance and problems of research on the influence of opinion leaders 'communication in electronic pharmacies on the consumers' perceived utilitarian, hedonistic value and purchasing behavior; (b) to reveal the conceptual content of opinion leaders' communication in electronic pharmacies; (c) describe consumers' perceived utilitarian and hedonistic value and purchasing behavior; (c) to conduct an empirical study of the impact of opinion leaders 'communications 
on e-pharmacies on consumers' perceived utilitarian, hedonistic value, and purchasing behavior and to summarize its findings.

Methodology of investigation. Theoretical studies of comparative analysis and systematization of scientific literature have been used in theoretical studies of the influence of opinion leaders' communication in electronic pharmacies on consumer perceived utilitarian, hedonistic value and purchasing behavior. To determine the empirical research on the perceptual utilitarian, hedonistic value, and purchasing behavior of opinion leaders' communication users, a quantitative method - an anonymous questionnaire - is used. The obtained empirical research results are processed and analyzed using the statistical program "SPSS Statistic 23.0", using descriptive statistics and methods of correlation and linear regression analysis.

Conclusions. Based on the results of correlation analysis, it can be stated that there is a statistically significant positive strong relationship between imaginative, informative, memorable, interesting messages communicated by opinion leaders and consumer- perceived utilitarian value, consumer-perceived value of hedonistic value. It can be argued that the communication message from opinion leaders gives consumers a sense of happiness and pleasure and is perceived as original and fascinating. Correlation analysis of the data shows a very strong effect on the perceived utilitarian value of opinion leaders' personal qualities (competent, objective, reliability, and physical attractiveness) and slightly lower on the consumer perceived hedonistic value. It can also be concluded that there is a statistically significant positive strong association between consumer perceived utilitarian value, consumer perceived hedonistic value, and consumer buying behavior.

Correspondence to: birute.pockeviciute@go.kauko.lt

Gauta 2019-10-01 